\title{
The Changes of P-fractions and Solubility of Phosphate Rock in Ultisol Treated by Organic Matter and Phosphate Rock
}

\author{
Sri Djuniwati*, Budi Nugroho, and Heru Bagus Pulunggono \\ Department of Soil Science and Land Resources Management, Faculty of Agriculture, Bogor Agriculture \\ University. Jl Meranti Kampus IPB Darmaga Bogor 16680. Phone +62-0251-8422371, "Corresponding \\ Author'se-mail:djuniwati_sri@yahoo.com.au
}

Received 18 October 2011 / accepted 23 July 2012

\begin{abstract}
Phosphorus $(\mathrm{P})$ is one of the essential elements for plant, however, its availability is mostly very low in acid soils. It is well documented that application of phosphate rock and organic matter are able to change the level of availability of $\mathrm{P}$-form in acid soils. The objective of the research were to evaluate the changes of P-fractions ( resin- $\mathrm{P}, \mathrm{NaHCO}_{3}$ $\mathrm{P}_{\mathrm{i}}$, and $\mathrm{NaHCO}_{3}-\mathrm{P}_{\mathrm{o}}$ ) and phosphate rock dissolution which were induced by application of organic matter (Imperata cylindrica, Pueraria javanica, dan Colopogonium mucunoides) and phosphate rock in Utisol Lampung. The experiment was designed in a completely randomized design with three factors and three replications. The first factor was the types of organic matter (I. cylindrica, P. javanica, and C. mucunoides), the second factor was the rate of organic matter $(0,2.5$, and $5 \%)$, and the third factor was the rate of phosphate rock $\left(0,40\right.$, and $\left.80 \mathrm{mg} \mathrm{P} \mathrm{kg}^{-1}\right)$. The results showed that in the rate of 0 and $1 \%$ organic matter, the type of organic matter did not affect P-fraction of $\mathrm{NaHCO}_{3}-\mathrm{P}_{\mathrm{i}}$, but in the rate of 2.5 and $5 \%, \mathrm{NaHCO}_{3}-\mathrm{P}_{\mathrm{i}}$ due to application of P. javanica, and C. mucunoides higher than due to application of I. cylindrica. However, the increasing rate of organic matter increased $\mathrm{NaHCO}_{3}-\mathrm{P}_{\mathrm{i}}$. Then, $\mathrm{P}$-fraction of Resin- $\mathrm{P}_{\mathrm{i}}$ was affected by the type of organic matter, the rate of organic matter, and the rate of phosphate rock, respectively. P-fraction of resin- $\mathrm{P}_{\mathrm{i}}$ due to application of $P$. javanica, and $C$. mucunoides was higher than due to application of $I$. cylindrica, but the effect of P. javanica, and C. mucunoides was not different. Increasing the rate of organic matter and phosphate rock increased $\mathrm{P}$-fraction of resin- $\mathrm{P}_{\mathrm{i}}$ and $\mathrm{NaHCO}_{3}-\mathrm{P}_{\mathrm{i}}$, but $\mathrm{P}$-fraction of $\mathrm{NaHCO}_{3}$ $\mathrm{P}_{\mathrm{o}}$ was not affected by all treatments. Meanwhile, dissolution of phosphate rock was affected by the kind of organic matter and soil reaction. In the rate of 5\% organic matter, dissolution of phosphate rock by application of I. cylindrica (70\%) was higher than P. javanica (26.6\%), and C. mucunoides $(33.5 \%)$, but in the rate of $1 \%$, the effect of I. cylindrica, P. javanica, and C. mucunoides were not different.
\end{abstract}

Keywords: C. mucunoides, I. cylindrica, P. javanica, phosphate rock, P-fractions

\section{INTRODUCTION}

Phosphorus $(\mathrm{P})$ is one of the essential macro nutrients, however, its availability is very low especially in acid soils, weathered soils, and soil from volcanic material that contains amorphous clay mineral (Allophanes). This low availability is caused by $\mathrm{P}$-fixation in the soils. Most of $\mathrm{P}$ added to the soil tends to be fixed even more than $90 \%$ so $\mathrm{P}$ availability status is very low, ranges between 10$20 \%$. P-fixation is caused by the present of soluble $\mathrm{Al}$ and $\mathrm{Fe}$ ions, oxides/hydroxides of $\mathrm{Al}$ and $\mathrm{Fe}$, and clay minerals in acid soils. In soils that highly weathered, it contains dominantly oxide minerals or kaolinite group and forms inorganic-P such as Fe-P and Al-P, while from allophane group forms Al-P. These kinds of P-inorganic forms are the P-forms that insoluble and unavailable.

J Trop Soils, Vol. 17, No. 3, 2012: 203-210

ISSN 0852-257X
Phophorus organic form is also the source of soil $\mathrm{P}$ which is fixed in the form of organic compound generally consists of three groups of P-organic compound i.e. phytin and its derivates, nucleic acid, and phospholipids. These forms are not available yet except phytin that can be absorbed by plant directly, although its absorption will be more effective when this compound is mineralized. Some methods for $\mathrm{P}$ fractionation have been developed for determination the forms of $\mathrm{P}$ in the soil such as by Hedley et al. (1982) and Tiessen and Moir (1993). Inorganic $\mathrm{P}$ that can be extracted by resin (resin-Pi) and $\mathrm{NaHCO}_{3}\left(\mathrm{NaHCO}_{3}-\mathrm{Pi}\right)$ and organic $\mathrm{P}\left(\mathrm{NaHCO}_{3}-\mathrm{Po}\right)$ had been agreed by some researchers as $\mathrm{P}$ available form, and its concentration in the soil affected by weathering process and soil management (Guo et al. 2000). Inorganic $\mathrm{P}$-resin (resin-Pi) and - $\mathrm{NaHCO}_{3}$-Pi are a labile $\mathrm{P}$ form and this form is mostly available for 
plant, as well as organic-P $\left(\mathrm{NaHCO}_{3}-\mathrm{Po}\right)$ as the source of $\mathrm{P}$ from the organic matter mineralization is a labile form, and those forms are in equilibrium with $\mathrm{P}$ - soil solution, which is immediately available for plants (De Brouwere et al. 2003; Beck and Sanchez, 1994; Bowman et al. 1978).

Mobility and availability of phosphorus (P) in the soil are affected by some factors such as $\mathrm{pH}$ (Sato and Comeford 2005), organic complexes of $\mathrm{Fe}$ and $\mathrm{Al}$ ( Borggaard et al. 2005), organic anions (Afif et al. 1995), amount and type of clay minerals (Penn et al. 2005), extractable $\mathrm{Fe}$ and $\mathrm{Al}$ oxides, hydroxides, and oxyhydroxides (Wiriyakitnateekul et al. 2005; Li et al. 2007), content of $\mathrm{Ca}, \mathrm{Fe}$, and $\mathrm{Al}$ in the soil, and phosphorus content in the mineral material (Tisdale et al. 1985). Availability of $\mathrm{P}$ in the soil can be increased by $\mathrm{P}$ fertilization and lime, and some studies showed that application of organic matter increases availability of $\mathrm{P}$ by decreasing $\mathrm{P}$ fixation that is caused by organic acids produced during organic matter decomposition, and it is able to chelate $\mathrm{Al} / \mathrm{Fe}$ so that $\mathrm{P}$ ion which is fixed at the $\mathrm{Al} / \mathrm{Fe}$ compound can be released and available for plant (Iyamuremye et al. 1996: Hartono et al. 2000).

One of the soil organic matter resources is crop biomass, especially green plant fertilizer i.e. Leguminoceae family. This plant has many species and has been used generally as a cover crops. Advantages in using organic matter from leguminous plant are because this plant can grow in the marginal soils in relatively fast growing, low ratio-C/N, can be harvested periodically, and can be decomposed quickly if it is buried into the soil. Another organic matter resource that is also potential and a lot of it in the marginal soils is alangalang (Imperata cylindrica). Alang-alang is a weed plant, fast growing plant, and able to grow in the poor soils, sandy soils, peat soils, and in the dry condition of soils (Aprisal 2000).

Meanwhile, a lot of phosphate rock (RP) is used as an alternative fertilizer of the conventional $\mathrm{P}$ such as TSP, SP-36/SP-18. However, low solubility of phosphate rock in the soil is a problem in developing it as a fertilizer $P$ resource. In general, phosphate rock solubility increases by application of acid treatment, therefore by giving acid to the rock phosphate, solubility and availability of $\mathrm{P}$ will increase. Some researchers also showed that a combination of phosphate rock and organic matter was able to increase P availability of soil P (Ikerra et al. 1994; Purnomo et al. 1999; Djuniwati et al. 2007; 2008). It is because organic acids from organic matter decomposition will be able to increase rock phosphate solubility (Sagoe et al. 1997).
The main objective of this research was to study the effects of organic matters types (Imperata cylindrical, Pueraria javanica, dan Colopogonium mucunoides), the rates of organic matters, and rate of $\mathrm{P}$ (phosphate rock) on the availability of $\mathrm{P}$ fraction (Pi-resin, P-inorganic and organic $\mathrm{NaHCO}_{3}$ ) and phosphate rock solubility in Ultisol Lampung.

\section{MATERIALS AND METHODS}

\section{Soil and Organic Materials}

The bulk soil used in this study was Ultisol that was collected from Terbanggi Besar, Middle Lampung District, for the surface 0-20 cm depth. This bulk soil samples was air dried, sieved with 2 $\mathrm{mm}$ size, and mixed evenly. Organic matters were sourced from biomass of alang-alang (I. cylindrical (Ic), leguminous plant $P$. javanica $(\mathrm{Pj})$, and $C$. mucunoides $(\mathrm{Cm})$, and phosphate rock (Rock-P) from Ciamis, West Java. This research was conducted at the soil chemical and fertility laboratory of the Department of Soil and Land Resources, Faculty of Agriculture, Bogor Agriculture University, Bogor.

Furthermore, organic matter from plant biomass i.e. $\mathrm{Pj}, \mathrm{Cm}$, and Ic (alang-alang) were cut to be smaller pieces, and then were decomposed. Soil sample, phosphate rock and organic matter characteristics before and after decomposed, and method of analysis are presented in Table 1 and 2.

\section{Experimental Design and Treatments}

This experiment was conducted in a completely randomized design with 3 factors and three replications. First factor was types of organic matter i.e. $\mathrm{Pj}, \mathrm{Cm}$, and $\mathrm{Ic}$, second factor was organic matter rates i.e. $0,1,2.5$, and $5 \%$, and third factor was phosphate rock rates equivalent to 0,40 , and $80 \mathrm{mg}$ $\mathrm{P} \mathrm{kg}^{-1}$. So there were $108(3 \times 4 \times 3 \times 3)$ experimental units.

\section{Incubation and Maintained}

Bulk soil sample was weighed equivalent to $200 \mathrm{~g}$ oven-dried-weight, then mixed with every kinds and rates of $\mathrm{Pj}, \mathrm{Cm}$, and $\mathrm{Ic}$ and phosphate rock corresponding to each treatment. The soil treated was put into the plastic bag, and then incubated for 4 weeks periods. During incubation period, soil moisture within each plastic bag was kept $70 \%$ of field capacity moisture by adding deionized water periodically. After the period of 
Table 1. Characteristics of soil sample and phosphate rock used.

\begin{tabular}{|c|c|c|}
\hline Characteristics & Methods & Value \\
\hline $\mathrm{pH} \mathrm{H}_{2} \mathrm{O}(1: 1)$ & pH meter & 4.66 \\
\hline C-organic (\%) & Walkley \& Black & 4.39 \\
\hline $\mathrm{N}$-total $(\%)$ & Kjeldahl & 0.19 \\
\hline Ratio $\mathrm{C} / \mathrm{N}$ & & 23.10 \\
\hline P- available $\left(\mathrm{mg} \mathrm{kg}^{-1}\right)$ & Bray I & 5.73 \\
\hline P- potential $\left(\mathrm{mg} \mathrm{kg}^{-1}\right)$ & $\mathrm{HCl} 25 \%$ & 714.90 \\
\hline $\operatorname{CEC}\left(\mathrm{cmol} \mathrm{kg}^{-1}\right)$ & $\mathrm{NH}_{4} \mathrm{OAc} \mathrm{pH} 7.0$ & 14.45 \\
\hline \multicolumn{3}{|l|}{ Bases $\left(\mathrm{cmol} \mathrm{kg}^{-1}\right)$ : } \\
\hline $\mathrm{Ca}_{\text {exchangeable }}$ & $\mathrm{NH}_{4} \mathrm{OAc} \mathrm{pH} 7.0$ & 1.33 \\
\hline $\mathrm{Mg}_{\text {exchangeable }}$ & $\mathrm{NH}_{4} \mathrm{OAc} \mathrm{pH} 7.0$ & 0.48 \\
\hline $\mathrm{K}_{\text {exchangeable }}$ & $\mathrm{NH}_{4} \mathrm{OAc} \mathrm{pH} 7.0$ & 0.72 \\
\hline $\mathrm{Na}_{\text {exchangeable }}$ & $\mathrm{NH}_{4} \mathrm{OAc} \mathrm{pH} 7.0$ & 0.61 \\
\hline $\mathrm{Al}_{\text {exchangable }}\left(\mathrm{cmol} \mathrm{kg}^{-1}\right)$ & $1 \mathrm{NKCl}$ & 2.16 \\
\hline $\mathrm{H}_{\mathrm{dd}}\left(\mathrm{cmol} \mathrm{kg}^{-1}\right)$ & $1 \mathrm{NKCl}$ & 0.31 \\
\hline Saturated $\mathrm{Al}(\%)$ & & 35.57 \\
\hline Fe-available $\left(\mathrm{mg} \mathrm{kg}^{-1}\right)$ & $0.05 N \mathrm{HCl}$ & 11.80 \\
\hline Mn-available $\left(\mathrm{mg} \mathrm{kg}^{-1}\right)$ & $0.05 N \mathrm{HCl}$ & 12.48 \\
\hline Texture (\%): & Pipet & \\
\hline sand & & 59.14 \\
\hline silt & & 17.24 \\
\hline clay & & 23.62 \\
\hline \multicolumn{3}{|c|}{ Phosphate rock from Ciamis: } \\
\hline P-total $(\%)$ & $\mathrm{HNO}_{3}+\mathrm{HClO}_{4}$ & 9.90 \\
\hline
\end{tabular}

Table 2. Chemical characteristics of organic matter $\mathrm{Pj}, \mathrm{Cm}$, and Ic before and after decomposed.

\begin{tabular}{llrrrrrr}
\hline \multirow{2}{*}{ Analysis } & \multirow{2}{*}{ Methods } & \multicolumn{3}{c}{ Before } & \multicolumn{3}{c}{ After } \\
\cline { 2 - 7 } & & $\mathrm{Pj}$ & $\mathrm{Cm}$ & $\mathrm{Ic}$ & $\mathrm{Pj}$ & $\mathrm{Cm}$ & $\mathrm{Ic}$ \\
\hline P-total (\%) & Wet digestion & 0.25 & 0.26 & 0.16 & - & - & - \\
& $\left(\mathrm{HNO}_{3}+\mathrm{HClO}_{4}\right)$ & & & & & & \\
C-organic (\%) & Mabeuse (dry & 53.45 & 51.98 & 54.05 & 50.73 & 48.74 & 48.58 \\
& oxidation) & 2.83 & 2.89 & 0.79 & 4.25 & 4.28 & 2.59 \\
N-total (\%) & Kjeldahl & 18.89 & 17.99 & 68.42 & 11.94 & 11.39 & 18.76 \\
C/N & - & 213.8 & 199.92 & 337.81 & - & - & - \\
C/P & - & - & - & - & 247.83 & 278.39 & 330.15 \\
\hline
\end{tabular}

incubation, the soil samples were air dried before analysis.

\section{Phosphate Analysis}

Parameters were observed after incubation i.e soil $\mathrm{pH}$, inorganic- $\mathrm{P}$ resin (resin- $\mathrm{P}_{\mathrm{i}}$ ) and inorganic$\mathrm{P} \mathrm{NaHCO}_{3}\left(\mathrm{NaHCO}_{3}-\mathrm{P}\right)$ and organic- $\mathrm{P} \mathrm{NaHCO}_{3}$ $\left(\mathrm{NaHCO}_{3}-\mathrm{P}_{0}\right)$ by using Tiessen and Moir Method (1993) and rock phosphate solubility by Solubility Method for Ca (Bolan and Hedley 1989). Phosphate rock solubility was measured by using indicator of the changes of calcium $(\mathrm{Ca})$ solubility value (Bolan and Hedley 1989). Phosphate rock solubility persentages were calculated based on the different of $\mathrm{Ca}$ in the soil treated by phosphate rock and control $(\triangle \mathrm{Ca})$ which was divided by $\mathrm{Ca}$ of phosphate rock $\times 100 \%$.

\section{Data Analysis}

Analysis of variance (ANOVA) for the completely randomized design was done to determine main and interactive effects of treatment. Multiple comparisons for means separation was analyzed by Duncan's Multiple Range Test (DMRT) with a significance level of $P<0.05$. 


\section{RESULTS AND DISCUSSION}

\section{Soil Characteristics}

Soil characteristics analysis (Table 1) showed that Lampung Ultisol was an acid soil with high organic-C content and low total-N, while total-P was high, but available P was very low (PPT 1983). It showed that soil $\mathrm{P}$ is generally in the fixation and unavailable forms. Due to high acidity, saturated $\mathrm{Al}$, and available $\mathrm{Fe}$, it is possible for $\mathrm{P}$ fixation. The low of CEC value is related with low content of clay. Furthermore, content of bases $\mathrm{Ca}^{-}{ }_{\text {exch }}$ and $\mathrm{Mg}_{-}{ }_{\text {exch }}$ were low and very low, but $\mathrm{K}_{\text {exch. }}$ and $\mathrm{Na}$ exch. were high and medium, respectively (PPT 1983). Because of these characteristics so this Ultisol was a soil with relatively low level of fertility.

\section{Organic Matter}

The organic matter analysis (Table 2) also showed that $\mathrm{C}$-organic content in biomass of $\mathrm{Pj}, \mathrm{Cm}$, and Ic was relatively the same, however, $\mathrm{N}$-content in biomass of $\mathrm{Pj}$ and $\mathrm{Cm}$ were higher than biomass of Ic, so $\mathrm{C} / \mathrm{N}$ ratio of biomass alang-alang (Ic) which was much higher than $\mathrm{Pj}$ and $\mathrm{Cm}$. It was due to Ic has higher lignin content than $\mathrm{Pj}$ and $\mathrm{Cm}$, while $\mathrm{Pj}$ and $\mathrm{Cm}$ have high $\mathrm{N}$-content. Because of high $\mathrm{C} / \mathrm{N}$ ratio of alang-alang (Ic) decomposition process was more difficult and took more longer time.

Interaction Effects of Types and Rates of Organic Matter and Phosphate Rock Application

Result of analysis of variance showed that combination of types of organic matter $\times$ rates of organic matter $\times$ phosphate rock only significantly affected soil $\mathrm{pH}$, while combination of types of organic matter $\times$ rates of organic matter affected inorganic- $\mathrm{P}\left(\mathrm{NaHCO}_{3}\right)$, phosphate rock solubility, and soil $\mathrm{pH}$. Besides that, inorganic- $\mathrm{P}\left(\mathrm{NaHCO}_{3}\right)$ $\left(\mathrm{NAHCO}_{3}-\mathrm{P}_{\mathrm{i}}\right)$ was significantly affected by combination of types of organic matter $\times$ rates of organic matter but also significantly affected by it single factor i.e. types of organic matter, rates of organic matter, and phosphate rock. However, inorganic-P resin (Resin-Pi) was only significantly affected by each single factor i.e. types of organic matter, rates of organic matter, and phosphate rock, except for P-organic $\left(\mathrm{NaHCO}_{3}\right)$ which were not affected by all treatments.

\section{Soil Reaction (Soil-pH)}

Result of Duncan Multiple Range Test about the effect of combination of types of organic matter $x$ rates of organic matter $\times$ phosphate rock on soil $\mathrm{pH}$ (Table 3) showed that based on the combination of rates organic matter $\times$ phosphate rock, so at each rate of organic matter Ic (I. cylindrica), increasing rates of phosphate rock did not affect soil $\mathrm{pH}$, and also at each rate of phosphate rock, increasing rates of organic matter Ic did not affect soil $\mathrm{pH}$. Beside that, effect of type of organic matter $P$. javanica (Pj) showed that at rate 0.1 and $2.5 \%$ of $\mathrm{Pj}$, increasing phosphate rock rates did not affect soil $\mathrm{pH}$, but rate $\mathrm{Pj} 5 \%$ with $80 \mathrm{mg} \mathrm{kg}^{-1} \mathrm{P}$ (phosphate rock), soil $\mathrm{pH}$ was higher than with $40 \mathrm{mg} \mathrm{kg}^{-1} \mathrm{P}$ (phosphate rock).

At each rate of phosphate rock, application of $\mathrm{Pj} 5 \%$ showed the highest soil $\mathrm{pH}$ and at application of $\mathrm{Pj} 2.5 \%$ soil $\mathrm{pH}$ was higher than application $\mathrm{Pj} 0$

Table 3. Effects of combination of types and rates of organic matter and phosphate rock on soil $\mathrm{pH}$.

\begin{tabular}{cclcc}
\hline Types of & Rates of organic & \multicolumn{3}{c}{ Rates of P (phosphate rock) $\left(\mathrm{mg} \mathrm{P} \mathrm{kg}^{-1}\right)$} \\
\cline { 2 - 5 } organic matter & $\begin{array}{c}\text { matter }(\%) \\
\text { Ic }\end{array}$ & 0 & 40 & 80 \\
\hline & 1 & $4.1 \mathrm{hi}$ & $4.2 \mathrm{hi}$ & $4.3 \mathrm{fghi}$ \\
& 2.5 & $4.2 \mathrm{hi}$ & $4.2 \mathrm{hi}$ & $4.3 \mathrm{fghi}$ \\
$\mathrm{Pj}$ & 5 & $4.3 \mathrm{fghi}$ & $4.2 \mathrm{hi}$ & $4.4 \mathrm{defgh}$ \\
& 0 & $4.1 \mathrm{hi}$ & $4.3 \mathrm{fghi}$ & $4.4 \mathrm{defgh}$ \\
& 1 & $4.2 \mathrm{i}$ & $4.2 \mathrm{hi}$ & $4.3 \mathrm{fghi}$ \\
& 2.5 & $4.6 \mathrm{defg}$ & $4.6 \mathrm{defg}$ & $4.7 \mathrm{~cd}$ \\
$\mathrm{Cm}$ & 5 & $6.5 \mathrm{a}$ & $5.8 \mathrm{~b}$ & $6.2 \mathrm{a}$ \\
& 0 & $4.1 \mathrm{hi}$ & $4.3 \mathrm{fghi}$ & $4.3 \mathrm{fghi}$ \\
& 1 & $4.4 \mathrm{defgh}$ & $4.4 \mathrm{defgh}$ & $4.4 \mathrm{defgh}$ \\
& 2.5 & $4.9 \mathrm{c}$ & $4.7 \mathrm{cde}$ & $4.8 \mathrm{cde}$ \\
& 5 & $6.4 \mathrm{a}$ & $6.4 \mathrm{a}$ & $6.4 \mathrm{a}$ \\
\hline
\end{tabular}

Note: Means followed by the same letters are not significantly different by DMRT at $\alpha 5 \%$ level different. 
and $1 \%$. Then, the effects of type of organic matter $\mathrm{Cm}$ had almost similar pattern with effect of $\mathrm{Pj}$, that was at each rate of phosphate rock, application of $\mathrm{Cm} 5 \%$ showed the highest soil $\mathrm{pH}$, and at addition of phosphate rock equivalent to 0,40 , and $80 \mathrm{mg} \mathrm{P}$ $\mathrm{kg}^{-1}$ were not different. Then, the effect of rate $\mathrm{Cm} 2.5 \%$ was higher than rate $\mathrm{Cm} 0$ and $1 \%$.

Among kind of organic matter it can be seen that at each rate of phosphate rock, effects of addition 0 and $1 \%$ of organic matter $\mathrm{Ic}, \mathrm{Pj}$, and $\mathrm{Cm}$ were not significantly different on soil $\mathrm{pH}$, but effects of organic matter $\mathrm{Pj}$ and $\mathrm{Cm}$ at rates of 2.5 and $5 \%$ resulted the higher soil $\mathrm{pH}$ than addition of Ic at the same rates. Then, at rates of organic matter $2.5 \%$, effects of organic matter $\mathrm{Cm}$ tended to be higher than effect $\mathrm{Pj}$ while at at rate of $5 \%$ effect $\mathrm{Cm}$ and $\mathrm{Pj}$ with application of rock phosphate equivalent to 0 and $80 \mathrm{mgP} \mathrm{kg}^{-1}$ were not significantly different and resulted the highest soil $\mathrm{pH}$, while at rates rock phosphate equivalent to 40 $\mathrm{mg} \mathrm{kg}^{-1} \mathrm{P}$, effct of $\mathrm{Cm}$ was higher than $\mathrm{Pj}$ on soil $\mathrm{pH}$.

Based on the above results, it was shown that soil $\mathrm{pH}$ was determined by types and rates of organic matter that was added, and addition of phosphate rock did not affect without adding organic matter. It was assumed that due to the present of organic acids that was produced during organic matter decomposition process. Bolan et al. (1994) and van Hees et al. (2000) stated that organic acids, mainly when it had low molecular weight, was able to chelate or to complex $\mathrm{Al}$ and or $\mathrm{Fe}$ in solution so its activities decreased and resulting to increase $\mathrm{pH}$. Djuniwati and Hartono (2002) also reported that addition of organic matter such as legume $(P$. javanica and $C$. muconoides) rates 2.5 and $5 \%$ decreased exchangeable- $\mathrm{Al}$ and $\mathrm{Fe}$ significantly, and increased soil $\mathrm{pH}$ of Ultisol Lampung.

The difference among kind of organic matter showed that effects of $\mathrm{Cm}$ on soil $\mathrm{pH}$ tended to be higher than $\mathrm{Pj}$, and the effects of both was higher than Ic (alang-alang). It was assumed that it was related to higher $\mathrm{C} / \mathrm{N}$ ratio of Ic (alang-alang) so that organic acids that was produced was more slower and more lower than result of organic matter $\mathrm{Pj}$ and $\mathrm{Cm}$ decomposition, so chelating resourced on the soil acidity becoming lower.

\section{Phosphate Rock Solubility}

Result of DMRT for the effects of combination of types and rates of organic matter on phosphate rock solubility (Table 4) showed that at type of organic matter Ic, increasing rates of Ic increased solubility of phosphate rock, but at type of organic matter $\mathrm{Pj}$ and $\mathrm{Cm}$ increasing rates of rock phosphate were occured at rates $1 \%$ while at rates of organic matter 2.5 and $5 \%$ rock phosphate solubility tended to decrease. It was assumed that it was related with soil $\mathrm{pH}$ (Table 3), i.e. effect of organic matter $\mathrm{Pj}$ and $\mathrm{Cm}$ at rate 2.5 and $5 \%$ was higher than effect of alang-alang (Ic). Effects of organic matter Ic resulted soil $\mathrm{pH}$ became very acid $(<4.5)$ while effects of organic matter $\mathrm{Pj}$ and $\mathrm{Cm}$ resulted soil pH became rather acid (5.8-6.5) (PPT 1983). The higher soil acidity, so effect of organic matter alangalang (Ic) to increase phosphate rock solubility would be higher than effect of organic matter $\mathrm{Pj}$ and $\mathrm{Cm}$.

Hammond et al. (1986) explained that phosphate rock solubility was determined by soil acidity, $\mathrm{P}$ adsoption capacity, Ca content in the soil, kinds of apatit mineral, particle size, and kind of it follower minerals, and Prasetyo cited by Purnomo (2002) proved that phosphate rock solubility was positively correlated with $\mathrm{Al}$-exchange and $\mathrm{H}$ ion in the red soils in West Java. Furthermore, Khasawaneh and Doll (1978 cited by Hammond et al. 1986) explained that soil factor that influenced phosphate rock solubility was $\mathrm{pH}, \mathrm{Ca}$ content, soil texture, and soil organic matter content. Phosphate rock solubility was higher at the soils with low $\mathrm{pH}$ (Chue et al. 1962). Increasing phosphate rock solubility on acid condition due to $\mathrm{H}$ ion in soil solution was able to release $\mathrm{PO}_{4}^{3-}$ anion and $\mathrm{Ca}^{2+}$ cation in the phosphate rock folowing this reaction (Bolan and Hedley 1989):

$$
\mathrm{Ca}_{10}\left(\mathrm{PO}_{4}\right)_{6} \mathrm{~F}_{2}+12 \mathrm{H}^{+} \rightleftarrows 10 \mathrm{Ca}^{2+}+6 \mathrm{H}_{2} \mathrm{PO}_{4}^{-}+2 \mathrm{~F}^{-}
$$

Table 4. Effects of kinds and rates of organic matter on phosphate rock solubility.

\begin{tabular}{|c|c|c|c|c|}
\hline \multirow{2}{*}{$\begin{array}{l}\text { Types of } \\
\text { Organic Matter }\end{array}$} & \multicolumn{4}{|c|}{ Rates of Organic Matter (\%) } \\
\hline & 0 & 1 & 2.5 & 5 \\
\hline & \multicolumn{4}{|c|}{..$(\%)$} \\
\hline Ic & 45.1 cdef & $59.7 \mathrm{abc}$ & $56.7 \mathrm{abcd}$ & $70.0 \mathrm{a}$ \\
\hline $\mathrm{Pj}$ & 52.1 cdef & $68.4 \mathrm{ab}$ & 40.9 defg & $26.6 \mathrm{~g}$ \\
\hline $\mathrm{Cm}$ & 45.7 cdef & $60.7 \mathrm{abc}$ & $38.3 \mathrm{efg}$ & $33.5 \mathrm{fg}$ \\
\hline
\end{tabular}

Note: Means followed by the same letters are not significantly different by DMRT at $\alpha 5 \%$ level different. 
Table 5. Effects of combination of kinds and rates of organic matter on soil Inorganic-P $\mathrm{NaHCO}_{3}\left(\mathrm{NaHCO}_{3}-\mathrm{P}\right)$.

\begin{tabular}{|c|c|c|c|c|}
\hline \multirow{2}{*}{$\begin{array}{l}\text { Types of Organic } \\
\text { Matter }\end{array}$} & \multicolumn{4}{|c|}{ Rates of Organic Matter (\%) } \\
\hline & 0 & 1 & 2.5 & 5 \\
\hline & & 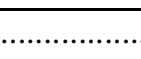 & & ... \\
\hline Ic & $27.82 \mathrm{fg}$ & 30.63 ef & $34.51 \mathrm{~cd}$ & $36.14 \mathrm{bc}$ \\
\hline $\mathrm{Pj}$ & $26.54 \mathrm{~g}$ & $31.82 \mathrm{de}$ & $38.40 \mathrm{~b}$ & $45.09 \mathrm{a}$ \\
\hline $\mathrm{Cm}$ & $30.41 \mathrm{ef}$ & $31.89 \mathrm{de}$ & $39.52 \mathrm{~b}$ & $44.10 \mathrm{a}$ \\
\hline
\end{tabular}

Note: Means followed by the same letters are not significantly different by DMRT at $\alpha 5 \%$ level different.

\section{Soil $P$ Fractions (Resin- $P_{i}$, Inorganic and Organic-P $\mathrm{NaHCO}_{3}$ )}

Result of DMRT for the effect of combination of types and rates of organic matter on soil inorganic- $\mathrm{P} \mathrm{NaHCO}_{3}\left(\mathrm{NaHCO}_{3}-\mathrm{P}\right)$ is shown in Table 5. Table 5 showed that at each type of organic matter increasing rates of organic matter was able to increase soil $\mathrm{NaHCO}_{3}-\mathrm{P}_{\mathrm{i}}$. At the rates of organic matter 0 and $1 \%$, effect of organic matter Ic, $\mathrm{Pj}$, and $\mathrm{Cm}$ the consentration of $\mathrm{NaHCO}_{3}-\mathrm{P}_{\mathrm{i}}$ did not significantly different, but at rates of organic matter 2.5 and 5\% effect of type of organic matter $\mathrm{Pj}$ and $\mathrm{Cm}$ resulted $\mathrm{NaHCO}_{3}-\mathrm{P}_{\mathrm{i}}$ higher than effect of alangalang (Ic).

Result of DMRT for single effects of types od organic matter, rates of organic matter, and rates of phosphate rock on the resin- $\mathrm{P}_{\mathrm{i}}$ and inorganic and organic $\mathrm{P}-\mathrm{NaHCO}_{3}$, and P-organic (Table 6) showed that effect of organic matter $\mathrm{Pj}$ and $\mathrm{Cm}$ on resin- $P_{i}$ was significantly higher than effect of Ic, and the same pattern occured on soil P-inorganic $\mathrm{NaHCO}_{3}\left(\mathrm{NaHCO}_{3}-\mathrm{P}_{\mathrm{i}}\right)$. The higher results of resin$\mathrm{P}_{\mathrm{i},} \mathrm{NaHCO}_{3}-\mathrm{Pi}$, and average of $\mathrm{NaHCO}_{3}$-Po were due to the effect of organic matter $\mathrm{Pj}$ and $\mathrm{Cm}$ than effect of organic matter Ic, because $\mathrm{P}$ content in organic matter $\mathrm{Pj}$ and $\mathrm{Cm}$ was higher than in Ic (Table 2). Besides that, it was assumed that it might also be related with the higher organic acids that produced by organic matter $\mathrm{Pj}$ and $\mathrm{Cm}$. These organic acids were able to play role as organic ligans that able to chelate $\mathrm{Al}$ and or $\mathrm{Fe}$, and to compete with adsorption site of $\mathrm{P}$, so it was released into soil solution or in the labile form and became available for plant. The research of Djuniwati et al. (2007 and 2008) was also shown that application of cover crops organic matter (C. pubescent and C. caeruleum) was able to increase available-P, organic-P, and inorganic-P of Latosol Darmaga.

Effect of rates of organic matter showed that increasing rates of organic matter also increased either Resin- $\mathrm{P}_{\mathrm{i}}$ or P-inorganic $\mathrm{NaHCO}_{3}\left(\mathrm{NaHCO}_{3}\right.$ $\mathrm{P}_{\mathrm{i}}$ ), because increasing rates would also increase $\mathrm{P}$ resource and organic acids produced. Thus, effect of rates of phosphate rock increased resin- $\mathrm{P}_{i}$ and $\mathrm{NaHCO}_{3}-\mathrm{P}_{\mathrm{i}}$, it was clearly because phosphate rock was $\mathrm{P}$ fertilizer, so increasing $\mathrm{P}$ fertilizer would increase resin- $\mathrm{P}_{\mathrm{i}}$ and $\mathrm{NaHCO}_{3}-\mathrm{P}_{\mathrm{i}}$ As long as organic ions from organic acids was able to compete with ortophosphate at adsorption site of $\mathrm{P}$, it exsistence in the soil would increase availability of $\mathrm{P}$ in the soil solution (Appelt et al. 1975; Traina et al. 1986). These anions were capable to substitute site of phosphate linkage through ligan exchange reaction as illustrated below:<smiles>O=C([M]O)OC=CC=[NH+][OH2+]</smiles>

In which $\mathrm{M}$ is metal surface, $\mathrm{OH}_{2}$ dan $\mathrm{H}_{2} \mathrm{PO}_{4}^{-}$are inorganic ligans while $\mathrm{HA}^{-}$is organic ligan.

\section{CONCLUSIONS}

Combination of types of organic matter $\mathrm{x}$ rates of organic matter significantly affected on inorganic-P, phosphate rock solubility, and soil $\mathrm{pH}$, while resin- $\mathrm{P}_{\mathrm{i}}$ was affected by its single factor i.e. types of organic matter, rates of organic matter, and rates of $\mathrm{P}$ (phosphate rock). Treatment of organic matter $\mathrm{Pj}$ and $\mathrm{Cm}$ on resin- $\mathrm{P}_{\mathrm{i}}$ was higher than organic matter Ic treatment, but between $\mathrm{Pj}$ and $\mathrm{Cm}$ treatment were not different. Then, increasing rates of organic matter and rates of phosphate rock, respectively, increased resin- $\mathrm{P}_{\mathrm{i}}$ and inorganic- $\mathrm{P}$ $\mathrm{NaHCO}_{3}\left(\mathrm{NaHCO}_{3}-\mathrm{P}\right)$, while P-organic $\mathrm{NaHCO}_{3}$ $\left(\mathrm{NaHCO}_{3}-\mathrm{P}_{\mathrm{o}}\right)$ was not affected by all treatments. Furthermore, at rates of organic matter 0 and $1 \%$, types of organic matter did not affect inorganic-P $\mathrm{NaHCO}_{3}\left(\mathrm{NaHCO}_{3}-\mathrm{P}_{\mathrm{i}}\right)$ but at rates 2.5 and $5 \%$ effect of organic matter $\mathrm{Pj}$ and $\mathrm{Cm}$ resulted inorganic- $\mathrm{P} \mathrm{NaHCO}_{3}\left(\mathrm{NaHCO}_{3}-\mathrm{P}\right)$ was higher than effect of Ic. At each kind of organic matter, increasing rates of organic matter increased $\mathrm{P}$ inorganic $\mathrm{NaHCO}_{3}\left(\mathrm{NaHCO}_{3}-\mathrm{P}\right)$.

Solubility of phosphate rock tended to related with soil acidity. At the rate of organic matter 5\%, 
Table 6. Single Effect of Types and Rates of Organic Matter, and rate of $\mathrm{P}$ (phosphate rock) on the Resin- $\mathrm{P}_{\mathrm{i}}$ and $\mathrm{P}$-inorganic $\mathrm{NaHCO}_{3}\left(\mathrm{NaHCO}_{3}-\mathrm{Pi}\right)$, and average of organic- $\mathrm{P} \mathrm{NaHCO}_{3}\left(\mathrm{NaHCO}_{3}-\mathrm{Po}\right)$.

\begin{tabular}{|c|c|c|c|}
\hline \multirow{2}{*}{ Treatments } & \multirow{2}{*}{ Resin- $P_{i}$} & \multicolumn{2}{|c|}{$\mathrm{NaHCO}_{3}$} \\
\hline & & P-inorganic & P-organic \\
\hline & & $\ldots \mathrm{mg} \mathrm{P} \mathrm{kg}^{-1}$ & \\
\hline \multicolumn{4}{|c|}{ Types of Organic Matter } \\
\hline Ic & $38.22 \mathrm{~b}$ & $32.28 \mathrm{~b}$ & 12.33 \\
\hline $\mathrm{Pj}$ & $47.46 \mathrm{a}$ & $35.46 \mathrm{a}$ & 12.90 \\
\hline $\mathrm{Cm}$ & $47.30 \mathrm{a}$ & $36.48 \mathrm{a}$ & 12.59 \\
\hline \multicolumn{4}{|c|}{ Rates of Organic Matter (\%) } \\
\hline 0 & $37.36 \mathrm{~d}$ & $28.26 \mathrm{~d}$ & 10.65 \\
\hline 1 & $40.43 \mathrm{c}$ & $31.45 \mathrm{c}$ & 12.03 \\
\hline 2.5 & $46.26 \mathrm{~b}$ & $37.48 \mathrm{~b}$ & 12.56 \\
\hline 5 & $53.26 \mathrm{a}$ & $41.78 \mathrm{a}$ & 15.19 \\
\hline \multicolumn{4}{|c|}{$\begin{array}{l}\text { Rates of } \mathrm{P} \text { (Rock Phosphate) } \\
\left(\mathrm{mg} \mathrm{P} \mathrm{kg}^{-1}\right)\end{array}$} \\
\hline 0 & $34.05 \mathrm{c}$ & $31.20 \mathrm{c}$ & 10.90 \\
\hline 40 & $43.69 \mathrm{~b}$ & $34.67 \mathrm{~b}$ & 12.85 \\
\hline 80 & $55.24 \mathrm{a}$ & $38.35 \mathrm{a}$ & 14.08 \\
\hline
\end{tabular}

Note: Means followed by the same letters are not significantly different by DMRT at $\alpha 5 \%$ level different.

solubility of phosphate rock in the soil that was applied organic matter treatment alang-alang (Ic) $(70.0 \%)$ was higher than soil that was applied organic matter $\mathrm{Pj}(26.6 \%)$ and $\mathrm{Cm}(33.5 \%)$, but at rate $1 \%$, solubility of phosphate rock with organic matter $\mathrm{Ic}, \mathrm{Pj}$, and $\mathrm{Cm}$ treatments were not significantly different.

\section{REFERENCES}

Afif E, V Barron and J Torrent. 1995. Organic matter delays but does prevent phosphate sorption by Cerrado soils from Brazil. Soil Sci 159: 207-211.

Appelt H, NT Coleman and PF Pratt. 1975. Interaction between organic compounds, minerals, and ions, in volcanic-ash derived soils: I. Adsorption of benzoate, $\mathrm{p}-\mathrm{OH}$ benzoate, salicylate, and phthalate ions. Soil Sci Am Proc 30: 623-630.

Aprisal. 2000. Kajian Reklamasi Lahan Marginal Alangalang dan Model Sistem Usaha Tani Terpadu untuk Membangun Pertanian Lestari di Daerah Tranmigrasi Pandan Wangi Peranap Riau. [Disertasi] Institut Pertanian Bogor (in Indonesian).

Beck MA and PA Sanchez. 1994. Soil phosphorus fraction dynamic during 18 years of cultivation on a Typic Paleudult. Soil Sci Soc Am J 58: 1424-1431.

Bolan NS and MJ Hedley. 1989. Dissolution of phosphate rocks in soils. I. Evaluation of extraction methods for the measurement of phosphate rocks dissolution. Fert Res 19: 65-75.

Bolan NS, R Naidu, S Mahimairaja and S Baskaran. 1994. Influence of low-molecular-weight organic acids on the solubilization of phosphates. Biol Fertil Soils 18:311-319.
Borggaard O K, B Raben-Lange, AI Gimsing and BW Strobel. 2005. Influence of humic substances on phosphate adsorption by aluminium and iron oxides. Geoderma 127: 270-279.

Bowman RA, SR Olsen and FS Watanabe. 1978. Greenhouse evaluation of residual phosphate by four phosphorus methods $\mathrm{n}$ neutral and calcareous soils. Soil Sci Soc Am J 42: 451-454.

Chue CR, WW Moshchler and GW Thomas. 1962. Rock phosphate transformation in acid soils. Soil Sci Soc Am Proc 26: 476-478.

De Brouwere K, A Thijs, H Maarten and R Merckx. 2003. Form and availability of soil phosphorus in temperate forests in southern Chile and Flanders. Gayana Bot 60: 17-23.

Djuniwati S and A Hartono. 2002. Studi erapan dan desorpsi P serta kelarutan fosfat alam pada Andisol dan Ultisol yang diperlakukan biomassa tanaman. Laporan Akhir Penelitian Project Grant QUE 2001/ 2002 (in Indonesian).

Djuniwati S, HB Pulunggono and Suwarno. 2008. Pengaruh bahan organik (Calopogonium caerolum) dan Fosfat alam terhadap aktivitas fosfatase dan P-tanah Latosol Darmaga. J Tanah Indon 1: 31-36.

Djuniwati S. HB Pulunggono and Suwarno. 2007. Pengaruh bahan organik (Centrosema pubescens) dan Fosfat alam terhadap aktivitas fosfatase dan Ptanah Latosol Darmaga. J Tanah Lingk 9: 10-15 (in Indonesian)

Guo F, RS Yost, NV Hue, CI Evensen and JA Silva. 2000. Changes in phophorus fractions in soil under intensive plant growth. Soil Sci Soc Am J 64: 1681-1689. 
Hammond LL, SH Chien and GW Easterwood. 1986. Agronomic effectiveness of Bayovar phosphate rock in soil with induce phosphorus retention. Soil Sci Soc Am J 50: 1601-1606.

Hartono A, PLG Vlek, A Moawad and A Rachim. 2000. Changes in phosphorus fractions on acidic soil induced by phosphorus fertilizer, organic matter, and lime. J Soil Sci Environ 2: 1-7.

Hedley MJ, JWB Stewart and BS Chauhan. 1982. Changes in inorganic and organic soil phosphorus fractions by cultivation practice and by laboratory incubations. Soil Sci Soc Am J 46: 970-976.

Ikerra TWD, PNS Mnkeni and RR Singh. 1994. Effect of added compost and farmyard manure on P release from Minjingu phosphate rocks and its uptake by maize. Norw J Agric Sci 8: 13-23.

Iyamuremye F, RP Dick and J Baham. 1996. Organic amendments and phosphorus dynamic; I. Phosphorus chemistry and sorption. Soil Sci 161: 436-443.

Li M, YI Hou and B Zhu. 2007. Phosphorus sorptiondesorption by purple soils of China in relation to their properties. Aust J Soil Res 45: 182-189.

Penn CJ, GI Mullins and LW Zelazny. 2005. Mineralogy in relation to phosphorus sorption and dissolved phosphorus losses in runoff. Soil Sci Soc Am J 69: 1532-1540.

PPT [Pusat Penelitian Tanah]. 1983. Term of Reference Type A No. 89/1983 P3MT - PPT Bogor, Indonesia (in Indonesian).

Purnomo J, IGP Putu Wigena and D Santoso. 1999. Pengaruh takaran fosfor dan bahan organic terhadap kadar dan serapan fosfor pada Typic
Dystropepts di Jambi. Prosiding Seminar Nasional Sumberdaya Tanah, Iklim dan Pupuk. Buku II. LidoBogor, 6-8 Desember 1999. Pusat Penelitian Tanah dan Agroklimat, Bogor, pp. 123-144 (in Indonesian). Sagoe CI, T Ando, K Kouno and T Nagaoka. 1997. Effects of organic-acid treatment of phosphate rocks on the phosphorus availability to Italian ryegrass. Soil Sci Plant Nutr 43: 1067-1072.

Sato $\mathrm{S}$ and NB Comerford. 2005. Influence of soil pH on inorganic phosphorus sorption and desorption in a humic Brazilian Ultisol. Rev Bras. Ciênc Solo 29: 685-694.

Tiessen H and JO. Moir 1993. Characterization of available $\mathrm{P}$ by sequential extraction. In: MR Carter (ed). Soil Sampling and Method of Analysis. Lewis Publ. Chelsea. MI, pp. 75-86.

Tisdale SL, WL Nelson and JD Beaton. 1985. Soil Fertility and Fertilizers. $4^{\text {th }}$ ed. Mcmillan Publishing Co. New York.

Traina SJ, G Sposito, D Hesterberg and U Kafkafi. 1986. Effect of $\mathrm{pH}$ and organic acids on organophosphate solubility and acid montmorilonitic soil. Soil Sci Soc Am J 50: 45-52.

van Hees PAW, US Lundstrom and R Giesler. 2000. Low molcular weight organic acids and their Alcomplexes in soil solution-composition, distribution and seasonal variation in three podzolized soils. Geoderma 94: 173-200.

Wiriyakitnateekul W, AS Suddhiprakam, I Kheorcenromne and RJ Gilkes. 2005. Extractable iron and aluminium predict the P-sorption capacity of Thai soils. Aust J Soil Res 43:757-766. 